\title{
Effects of the Acetylene Compound from Atractylodes Rhizome on Experimental Gastric Ulcers Induced by Active Oxygen Species
}

\author{
Tetsuro Sakurai, Hiroki Sugawara, Ken-ichi Saito, and Yoshihiro Kano* \\ Hokkaido Institute of Pharmaceutical Sciences, 7-1, Katsuraoka-cho, Otaru 047-02, Japan. \\ Received March 11, 1994; accepted June 8, 1994
}

This study was conducted to determine the beneficial effects of treating digestive disorders of $(6 E, 12 E)$ tetradecadiene-8,10-diyne-1,3-diol diacetate (TDEYA) detected in the plasma in hydrolyzed form: $(6 E, 12 E)$ tetradecadiene-8,10-diyne-1,3-diol (TDEY), following the oral administration of a decoction of Atractylodes rhizome to rats. Assessment was also made of the efficacy of TDEYA in experimental gastric disorder models.

Oral administration of TDEYA at doses of 300 to $500 \mathrm{mg} / \mathrm{kg}$ suppressed the formation of gastric lesions induced by indometacin in a dose-dependent manner. TDEYA at a dose of $200 \mathrm{mg} / \mathrm{kg}$ suppressed gastric lesions induced by an ischemia-reperfusion injury model. TDEYA at doses of 100 to $300 \mathrm{mg} / \mathrm{kg}$ did not show suppressive effects on water immersion stress-induced gastric lesions. TDEYA showed no active oxygen species scavenging action, nor did it have any effect on superoxide dismutase activity in the stomach tissue. TDEYA at doses of $200 \mathrm{to} 500 \mathrm{mg} / \mathrm{kg}$ significantly suppressed xanthine oxidase (XO) activity in the stomach tissue follwing its oral administration.

The suppressive effects of TDEYA on lesion formation induced by indometacin and ischemia-reperfusion injury models would thus appear to be due in part to the inhibition of XO activity in the stomach tissue.

Keywords gastric injury; acetylene compound; xanthine oxidase activity; active oxygen species; ischemia-reperfusion

Atractylodes japonica KoIDzumi et KiTAmura (Compositae) is a perennial plant native to North Asia. In the Japanese Pharmacopoeia, this plant is described as the original plant of Atractylodes rhizome. Atractylodes rhizome has been used for centuries as a therapeutic agent for edema, digestive disorders and arthritis in China and Japan. In particular, it is an important crude drug which is prescribed in Chinese medicines for digestive diseases.

Different results have been reported regarding the action of Atractylodes rhizome. For example, the benzene extract of Atractylodes rhizome has no suppressive effect on water immersion stress-induced gastric lesions or gastric acid secretion, and it does not affect the intestinal transport of charcoal meal. ${ }^{1)}$ A water extract does not exert a suppressive effect on water immersion stress-induced gastric lesions in mice. ${ }^{2)}$ Methanol $(50 \%)$ extract of Atractylodes rhizome at doses of 50 to $200 \mathrm{mg} / \mathrm{kg}$ has been shown to have a suppressive effect on water immersion stress-induced gastric lesions, ${ }^{3)}$ and an acetone extract at a dose of $500 \mathrm{mg} / \mathrm{kg}$ also suppresses $\mathrm{HCl}-$ ethanol-induced gastric mucosal membrane lesions. ${ }^{4)}$

Recent studies have indicated that active oxygen species play an important role in the pathogenesis of various gastric mucosal injuries, ${ }^{5,6)}$ and that some active oxygen species scavengers have a protective effect against mucosal injury induced by the experimental gastric injury model. ${ }^{7)}$ It is generally accepted that one source of active oxygen radicals is xanthine oxidase $(\mathrm{XO}),{ }^{8}$ indicating that $\mathrm{XO}$ plays an important role in the etiology of digestive disorders.

We previously reported that $(6 E, 12 E)$-tetradecadiene8,10-diyne-1,3-diol diacetate (TDEYA) was detected in plasma in a hydrolyzed form: $(6 E, 12 E)$-tetradecadiene8,10-diyne-1,3-diol (TDEY), following the oral administration of Atractylodes rhizome extract to rats. ${ }^{9)}$ TDEYA and TDEY also showed an inhibitory effect on XO. ${ }^{10}$ ) Based on these results and the pharmacological effects attributed to the plant from ancient times, we designed a series of studies to examine its efficacy toward experimental digestive disorder models induced by active oxygen species: indometacin-induced lesions, water immersion stressinduced gastric lesions and ischemia-reperfusion injury model. In addition, we also studied the properties of TDEYA-related radical scavenging action, superoxide dismutase (SOD) activity stimulation and $\mathrm{XO}$ inhibitory activity in the stomach tissue.

\section{MATERIALS AND METHODS}

Chemicals and Animals Indometacin, 16,16-dimethyl prostaglandin $\mathrm{E}_{2}\left(16-\operatorname{dimPGE}_{2}\right)$ and $\mathrm{SOD}$ were purchased from Sigma Chemical Co. (U.S.A.). Allopurinol and atropine were obtained from Nacalai Tesque, Inc. (Kyoto, Japan). Pyrogallol, dithioerythritol, dimethyl sulfoxide (DMSO) and phenylmethyl sulfonyl fluoride (PMSF) were purchased from Wako Pure Chemical Industries, Ltd. (Osaka, Japan). All other chemicals were of guaranteed reagent grade. TDEYA was isolated from Atractylodes rhizome as described previously. ${ }^{11)}$

Male Sprague-Dawley rats (Sankyo Labo Service Co., Ltd.), 5 weeks, 100-120 g, were housed and maintained at $25 \pm 0.5^{\circ} \mathrm{C}$ and constant humidity $(55 \%)$. The rats were fed on a commercial pellet food diet (MF, Oriental Yeast Co., Ltd.) and had free access to tap water.

Production of Gastric Injury Models IndometacinInduced Lesions ${ }^{12)}$ : Rats weighing about $200 \mathrm{~g}$ were deprived of food for $24 \mathrm{~h}$ before the start of the experiment. Indometacin $(20 \mathrm{mg} / \mathrm{kg})$ suspended with $0.5 \%$ tragacanth gum was administered via the stomach tube, and $4 \mathrm{~h}$ later, the animals were sacrificed. The stomach was removed, fixed by inflation with $10 \mathrm{ml}$ of $2 \%$ formalin, and then incised along the greater curvature. The length $(\mathrm{mm})$ of each lesion was measured under a dissecting microscope $(\times 10)$, and the sum of the lengths of lesions in each animal was calculated. Test drugs emulsified with $0.5 \%$ Tween 80 and vehicle only for the control group were administered 
orally $30 \mathrm{~min}$ before treatment with indometacin.

Water Immersion Stress-Induced Gastric Lesions ${ }^{13)}$ : Rats weighing about $200 \mathrm{~g}$ were deprived of food and water for $3 \mathrm{~h}$ before the start of the experiment. They were immobilized individually in separate compartments of a stress-cage and then immersed up to their xiphoid in a water bath maintained at $24 \pm 1^{\circ} \mathrm{C}$. After $12 \mathrm{~h}$, the animals were sacrificed. The stomach was removed and the stomach damage was then measured in the same manner as described under "Indometacin-induced lesions." Test drugs were administered orally $30 \mathrm{~min}$ before the stress treatment.

Ischemia-Reperfusion Injury Model ${ }^{14)}$ : Rats weighing about $250-280 \mathrm{~g}$ were deprived of food for $48 \mathrm{~h}$ before the experiment. The animals were then anesthetized with $50 \mathrm{mg} / \mathrm{ml} / \mathrm{kg}$ of pentobarbital sodium. The abdomen was opened and the pylorus was ligated. A carotid artery was cannulated with polyethylene tubing to monitor blood pressure (Multipurpose polygraph, Nihonkoden) and to withdraw and reinfuse blood. Body temperature was maintained at $36-37^{\circ} \mathrm{C}$ by a heat lamp. After the blood pressure stabilized, $1 \mathrm{ml}$ of $0.1 \mathrm{~N} \mathrm{HCl}$ per $100 \mathrm{~g}$ body weight was instilled into the stomach via the gastric tube. Blood was withdrawn from the carotid artery into a syringe containing $0.5 \mathrm{ml}$ of saline (100 units heparin $/ \mathrm{ml}$ saline). The mean systemic blood pressure was reduced to between 20 and $30 \mathrm{mmHg}$ by the initial bleeding and was maintained at that level for $20 \mathrm{~min}$. The withdrawn blood was then reinfused, and $20 \mathrm{~min}$ later the rat was sacrificed. The stomach was treated in the same manner as described previously. The gastric mucosal lesion area $\left(\mathrm{mm}^{2}\right)$ was measured separately under a microscope with a square grid $(\times 10)$. TDEYA and allopurinol were administered orally at $30 \mathrm{~min}$, and $12 \mathrm{~h}$ and $30 \mathrm{~min}$ prior to the anesthetization treatment, respectively.

Active Oxygen Species Scavenging Activity of TDEYA The method is based on the modifications of Marklund. ${ }^{15)}$ Pyrogallol solution $(6 \mathrm{~mm}$ in $10 \mathrm{~mm} \mathrm{HCl})$ of $0.1 \mathrm{ml}$ was added to a mixture consisting of $88 \mathrm{~mm}$ tris-cacodylic acid $(\mathrm{pH} 8.4,1.7 \mathrm{ml}), 5 \mathrm{~mm}$ EDTA $(0.6 \mathrm{ml}), \mathrm{DMSO}(0.6 \mathrm{ml})$ and the sample $(10 \mu \mathrm{l})$. Absorbance was monitored at $420 \mathrm{~nm}$ with a spectrophotometer (Shimadzu UV3000). The time course of active oxygen radical generation by autooxidation of pyrogallol was expressed by the increasing absorbance. The reaction was carried out at $25^{\circ} \mathrm{C}$.

Increase in SOD-Like Activity in the Stomach Tissue by TDEYA The method was carried out according to the modification of Oka et al ${ }^{16)}$ Rats weighing about $200 \mathrm{~g}$ were deprived of food for $24 \mathrm{~h}$ and were administered $1 \mathrm{ml}$ of TDEYA $(200 \mathrm{mg} / \mathrm{kg})$. Each animal was sacrificed 10 , 30,60 or $120 \mathrm{~min}$ later, and the stomach was removed and homogenized with $50 \mathrm{~mm}$ Tris- $\mathrm{HCl}$ buffer (pH 7.4). The homogenate was centrifuged at $20000 \times g$ for $20 \mathrm{~min}$ at $0^{\circ} \mathrm{C}$. The supernatant was measured for SOD activity in the same manner as described under "Radical scavenging activity of TDEYA."

Time Course of XO Inhibitory Activity in the Stomach Tissue The method is based on the modifications of Perry et al. ${ }^{5)}$ Rats weighing about $250 \mathrm{~g}$ were deprived of food for $24 \mathrm{~h}$ and were administered $1 \mathrm{ml}$ of TDEYA $(200,500$ $\mathrm{mg} / \mathrm{kg}$ ). Animals were sacrificed $30,60,120$, or $240 \mathrm{~min}$ later, and the stomach was removed. Each stomach was rinsed with water, and was homogenized with $50 \mathrm{~mm}$ phosphate buffer ( $\mathrm{pH}$ 7.8) containing dithioerythritol, EDTA and PMSF as a factor to protect the SH groups and to inhibit ion formation and protease. The homogenate was centrifuged at $20000 \times \boldsymbol{g}$ for $20 \mathrm{~min}$ at $0^{\circ} \mathrm{C}$. The enzyme was assayed with xanthine as the substrate in a $100 \mathrm{~mm}$ phosphate buffer ( $\mathrm{pH}$ 7.4). The velocity of the reaction was monitored at $295 \mathrm{~nm}$ with a spectrophotometer for $5 \mathrm{~min}$. Activity was expressed as milliunits per $100 \mu \mathrm{g}$ protein, and represented the number of moles xanthine oxidized to uric acid per minute at $30^{\circ} \mathrm{C}$. The amount of protein was calculated according to the method of Markwell et al. ${ }^{17)}$

Statistical Analyses of Data Data obtained from the experiments are expressed as means \pm S.E. The values were analyzed by a one-way analysis of variance (ANOVA) and the group means were compared by Tukey's test for multiple comparison. A value of $p<0.05$ was considered significant.

\section{RESULTS}

Effects of TDEYA on Gastric Injury Effect on Indometacin-Induced Lesions: The control group showed multiple lesions along the glandular portion. TDEYA suppressed the formation of gastric lesions in a dosedependent manner. TDEYA at doses of 300 and 500 $\mathrm{mg} / \mathrm{kg}$ significantly reduced lesion formation. 16-dimPGE ${ }_{2}$ strongly reduced lesion formation at a dose of $0.025 \mathrm{mg} / \mathrm{kg}$ (Table I). Administration of TDEYA at a dose of 500 $\mathrm{mg} / \mathrm{kg}$ had no effect on ordinary behavior or the external view in rats during a period of 2 weeks.

Effect on Water Immersion Stress-Induced Gastric Lesions: TDEYA at doses of 100,200 and $300 \mathrm{mg} / \mathrm{kg}$ did not result in statistically significant differences from the control. Atropine at a dose of $10 \mathrm{mg} / \mathrm{kg}$ significantly reduced lesion formation (Table II).

Effect on Ischemia-Reperfusion Injury Model: TDEYA suppressed the formation of gastric lesions in a dosedependent manner. TDEYA at a dose of $200 \mathrm{mg} / \mathrm{kg} \mathrm{sig}$ nificantly $(p<0.05)$ reduced the area of gastric lesions. Allopurinol (XO inhibitor) at doses of $50 \mathrm{mg} / \mathrm{kg} \times 2$ also significantly reduced gastric lesions (Table III).

Active Oxygen Species Scavenging Activity of TDEYA The time course of active oxygen species generation is shown in Fig. 1. SOD inhibited the auto-oxidation of

TABLE I. Effect of TDEYA on Indometacin-Induced Gastric Lesions after Administration of Vehicle (Control) or Different Doses of TDEYA and 16-dimPGE 2 in Rats

\begin{tabular}{lcccc}
\hline Treatment & $\begin{array}{c}\text { Dose } \\
(\mathrm{mg} / \mathrm{kg}, \text { p.o. })\end{array}$ & $\begin{array}{c}\text { No. of } \\
\text { rats }\end{array}$ & $\begin{array}{c}\text { Lesion index } \\
(\mathrm{mm})\end{array}$ & $\begin{array}{c}\text { Inhibition } \\
(\%)\end{array}$ \\
\hline Control & - & 14 & $11.7 \pm 1.9$ & - \\
TDEYA & 100 & 7 & $10.4 \pm 1.3$ & 11.1 \\
& 300 & 6 & $4.0 \pm 1.3^{a)}$ & 65.8 \\
& 500 & 6 & $2.6 \pm 1.0^{b)}$ & 77.7 \\
16-dimPGE & 0.025 & 7 & $2.9 \pm 0.4^{b)}$ & 75.2 \\
\hline
\end{tabular}

Each value represents the mean \pm S.E. A significant difference from the control was set at $a$ ) $p<0.05$ and $b$ ) $p<0.01$. 
TABLE II. Effect of TDEYA on Water Immersion Stress-Induced Gastric Lesions after Administration of Vehicle (Control) or Different Doses of TDEYA and Atropine in Rats

\begin{tabular}{ccccc}
\hline \hline Treatment & $\begin{array}{c}\text { Dose } \\
(\mathrm{mg} / \mathrm{kg}, \text { p.o. })\end{array}$ & $\begin{array}{c}\text { No. of } \\
\text { rats }\end{array}$ & $\begin{array}{c}\text { Lesion index } \\
(\mathrm{mm})\end{array}$ & $\begin{array}{c}\text { Inhibition } \\
(\%)\end{array}$ \\
\hline Control & - & 13 & $24.7 \pm 1.8$ & - \\
TDEYA & 100 & 7 & $28.6 \pm 3.3$ & -15.7 \\
& 200 & 6 & $27.7 \pm 5.4$ & -12.1 \\
Atropine & 300 & 7 & $25.2 \pm 2.9$ & -2.0 \\
& 10 & 7 & $4.7 \pm 0.8^{a)}$ & 81.0 \\
\hline
\end{tabular}

Each value represents the mean \pm S.E. A significant difference from the control was set at a) $p<0.01$

TABLE III. Effect of TDEYA on Gastroc Lesions Induced by IschemiaReperfusion Injury after Administration of the Vehicle (Control) or Different Doses of TDEYA and Allopurinol in Rats

\begin{tabular}{lcccc}
\hline \hline Treatment & $\begin{array}{c}\text { Dose } \\
(\mathrm{mg} / \mathrm{kg}, \text { p.o. })\end{array}$ & $\begin{array}{c}\text { No. of } \\
\text { rats }\end{array}$ & $\begin{array}{c}\text { Lesion index } \\
\left(\mathrm{mm}^{2}\right)\end{array}$ & $\begin{array}{c}\text { Inhibition } \\
(\%)\end{array}$ \\
\hline Control & - & 8 & $107.3 \pm 18.4$ & - \\
TDEYA & 100 & 6 & $95.8 \pm 16.5$ & 10.7 \\
& 200 & 6 & $52.3 \pm 12.0^{a)}$ & 51.3 \\
Allopurinol & $50(\times 2)$ & 5 & $31.2 \pm 10.1^{b)}$ & 70.9 \\
\hline
\end{tabular}

Each value represents the mean \pm S.E. A significant difference from the control was set at $a$ ) $p<0.05$ and $b$ ) $p<0.01$.

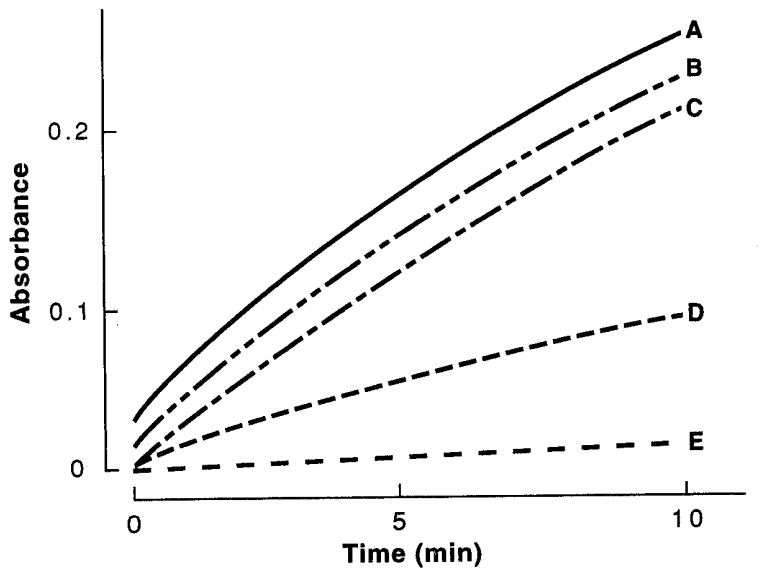

Fig. 1. Active Oxygen Species Scavenging Activity of TDEYA

Active oxygen species scavenging activity was expressed for the suppression of increasing absorbance by the auto-oxidation of pyrogallol. Absorbance was monitored at $420 \mathrm{~nm}$ with a spectrophotometer for $10 \mathrm{~min}$. A, control; B, TDEYA $50 \mu \mathrm{g} / \mathrm{ml}$; C, TDEYA $200 \mu \mathrm{g} / \mathrm{ml} ; \mathrm{D}$, SOD $0.2 \mu \mathrm{g} / \mathrm{ml} ; \mathrm{E}$, SOD $1.0 \mu \mathrm{g} / \mathrm{ml}$.

pyrogallol by active oxygen species scavenging activity (approximately $60 \%$ ) at a concentration of $0.2 \mu \mathrm{g} / \mathrm{ml}$, and it was almost completely scavenged at $1.0 \mu \mathrm{g} / \mathrm{ml}$. TDEYA and TDEY showed no active oxygen species scavenging activity at concentrations of 50 and $200 \mu \mathrm{g} / \mathrm{ml}$, respectively.

Increase in SOD-Like Activity in the Stomach Tissue by TDEYA The results of an assay indicated an increase of $0.253 \pm 0.002$ up to $10 \mathrm{~min}$ following the addition of pyrogallol (Fig. 2). When adding the homogenate of the control group, absorbance was reduced to $0.118 \pm 0.005$ (approximately 50\%). TDEYA treatment of the stomach tissue showed reduced absorbance in all cases, but significant differences from the control group were not

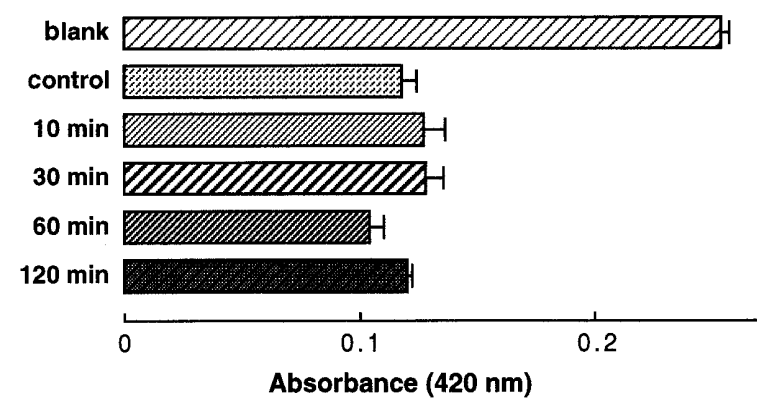

Fig. 2. Time Course of SOD-Like Activity in Stomach Tissue after Oral Administration of TDEYA

Activity was expressed as the suppression of increasing absorbance by the auto-oxidation of pyrogallol. Absorbance was monitored at $420 \mathrm{~nm}$ with a spectrophotometer for $10 \mathrm{~min}$. A buffer solution and the supernatant of tissue homogenate were used as the blank and control, respectively. Each value represents the mean \pm S.E.; $n=5$.

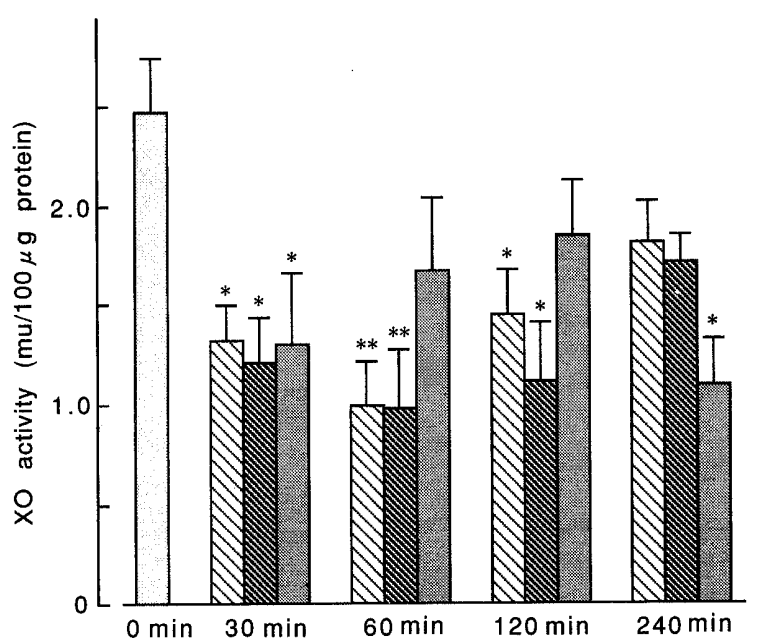

Fig. 3. Time Course of XO Activity in Stomach Tissue after Oral Administration of TDEYA (200 and $500 \mathrm{mg} / \mathrm{kg})$ and Allopurinol $(50 \mathrm{mg} / \mathrm{kg} \times 2)$

, control; $\mathbb{Q}$, TDEYA $200 \mathrm{mg} / \mathrm{kg}$; TDEYA $500 \mathrm{mg} / \mathrm{kg}$; , allopurinol $50 \mathrm{mg} / \mathrm{kg} \times 2$. Administration of the vehicle only to rats was used as the $0 \mathrm{~min}$. Each value represents the mean \pm S.E.; $n=12-5$. A significant difference from the control was set at ${ }^{*} p<0.05$ and ${ }^{* *} p<0.01$.

found.

Time Course of XO Inhibitory Activity in the Stomach Tissue TDEYA at doses of 200 to $500 \mathrm{mg} / \mathrm{kg}$ significantly inhibited XO in the stomach tissue, but not in a dosedependent manner. XO activity in the stomach tissue of the control group was $2.48 \pm 0.27 \mathrm{mU} /$ protein (Fig. 3). TDEYA, $500 \mathrm{mg} / \mathrm{kg}$, inhibited XO activity in the stomach tissue at 60 and $120 \mathrm{~min}$ after oral administration, to $0.99 \pm 0.28(p<0.01)$ and $1.12 \pm 0.29(p<0.05) \mathrm{mU} /$ protein, respectively. The extent of inhibition by TDEYA at these times was 60.1 and $54.8 \%$, respectively. The inhibitory activity of TDEYA toward XO gradually decreased after $60 \mathrm{~min}$. Allopurinol showed an inhibitory effect at $240 \mathrm{~min}$.

\section{DISCUSSION}

Active oxygen species have been shown to be significantly involved in the pathogenesis of gastric mucosal injury. Indomethacin is an inhibitor of cycrooxygenase, ${ }^{18,19}$ ) and depresses the output of prostaglandin $\mathrm{E}_{2}\left(\mathrm{PGE}_{2}\right)$, 
which has a strong effect on various experimental gastric ulcer models. ${ }^{20)}$ Indometacin-induced lesions may thus cause a decrease in endogenous $\mathrm{PGE}_{2}$. This has yet to be confirmed, but lesions have been shown not to develop following an indometacin administration at a dose sufficient to completely suppress $\mathrm{PGE}_{2} \cdot{ }^{21)}$ One major factor contributing to indometacin-induced lesions may be the generation of an active oxygen species. ${ }^{22}$ )

Water immersion stress-induced gastric lesions may depend on an increase in gastric juice secretion and a decrease in gastric blood flow due to gastric movement. Yoshikawa et al. found that lipid peroxidation in the gastric mucosa increased before the appearance of mucosal ulcers, and ulcer formation decreased following SOD administration. ${ }^{23)}$ Active oxygen species are thus shown to be clearly important to the pathogenesis of experimental gastric injury.

TDEYA at oral doses of 300 to $500 \mathrm{mg} / \mathrm{kg}$ dose dependently reduced indometacin-induced lesion formation. TDEYA at oral doses of 100 to $300 \mathrm{mg} / \mathrm{kg}$ did not depress gastric lesion formation caused by water immersion stress. The absence of inhibitory activity of TDEYA toward water immersion stress-induced gastric lesions cannot be explained based on the assumption that both ulcers are caused by the same mechanism. However, based on the mechanism and preparation period of water immersion stress-induced gastric lesions, TDEYA may be considered to have no inhibitory action on gastric juice secretion, in contrast to atropine, and to be metabolized rapidly to a non-active substance in the body. The in vivo pharmacokinetics of TDEYA will be studied further.

TDEYA reduced ulcer formation caused by indometacin, and thus, examination was made of the properties of TDEYA as an active oxygen species. Many factors contribute to the generation of active oxygen species in tissue. The most logical explanation for oxygen radical generation in the stomach would involve the XO system, ${ }^{8,24)}$ since gastrointestinal tissue has low $\mathrm{SOD}^{25}$ ) and high XO activity. ${ }^{26)}$ Salim et al. found allopurinol to be equally efficacious and superior to cimetidine for treating duodenal ulcer relapse. ${ }^{27)}$

Based on the above, and that TDEYA showed XO inhibitory activity in in vitro experiments, an ischemiareperfusion injury model should facilitate determining whether the reduction in gastric lesion formation is due to the XO inhibitory activity of TDEYA.

Studies on the mechanism of gastric lesion formation in this experimental model suggest the following process: with ischemia, ATP is catabolized to intermediates such as adenosine, ${ }^{28)}$ inosine, hypoxanthine and xanthine, ${ }^{29)}$ leading to the conversion of xanthine dehydrogenase to its XO form. ${ }^{30,31)}$ By reperfusion, XO catalyzes the reaction between hypoxanthine or xanthine and oxygen to release active oxygen radical species which cause cellular or tissue injury.

TDEYA and allopurinol reduced lesion formation, indicating that the inhibitory activity of TDEYA on ischemia-reperfusion is due to $\mathrm{XO}$ inhibition in the stomach tissue.

An increase in the number of conjugated unsaturated bonds would appear to be associated with better quenching ability toward active oxygen species. $^{32,33,34)}$ TDEYA would thus appear to possess scavenging activity toward active oxygen species such as SOD. To determine whether TDEYA actually expresses this action, the pyrogallol method was used to assay SOD. As summarized in Fig. 1 , the generation of active oxygen species increased timedependently. SOD at 0.2 and $1.0 \mu \mathrm{g} / \mathrm{ml}$ clearly showed active oxygen species scavenging activity, while TDEYA and TDEY did not. TDEYA did not stimulate SOD activity in the stomach tissue at any time (Fig. 2). Thus, TDEYA does not possess active oxygen species scavenging action nor does it exert a stimulatory effect on SOD activity in the stomach tissue.

By measurement of enzyme activity, TDEYA was shown to inhibit XO activity in the stomach tissue after oral administration (Fig. 3). This action did not have a durable effect: TDEYA at a dose of $500 \mathrm{mg} / \mathrm{kg}$ inhibited XO activity by only $30.7 \%$ at $240 \mathrm{~min}$. This may be the reason for the absence of the effect of TDEYA on water immersion stress-induced gastric lesions. TDEYA at a dose of $200 \mathrm{mg} / \mathrm{kg}$ may show a maximum effect on XO inhibition, since its effect was not dose-dependent at 200 or 500 $\mathrm{mg} / \mathrm{kg}$. Ito et al. reported gastric acid to be an important factor in the ischemia-reperfusion injury model. TDEYA may thus have protective action on stomach tissue through mucus or PGE 2 secretion. Other actions of TDEYA on the stomach are now being investigated.

Acetylene compounds have anti-mycotic, ${ }^{35)}$ antinociceptive, ${ }^{36)}$ anti-cancer ${ }^{37)}$ and anti-human immunodeficiency virus activity. ${ }^{38)}$ This study shows acetylene compounds to have a anti-ulcer activity toward some experimental gastric disorders. This action is due in part to the inhibition of $\mathrm{XO}$ activity, but not to active oxygen species scavenging action or to an increase in SOD activity in the stomach tissue.

Acknowledgement The authors thank Mr. Sakurai for valuable advice. This study was supported by research funds from "The Traditional Oriental Medical Science Program" of the Public Health Bureau of the Tokyo Metropolitan Government.

\section{REFERENCES}

1) J. Yamahara, T. Sawada, T. Tani, T. Nishino, I. Kitagawa, H. Fujimura, Yakugaku Zasshi, 97, 873 (1977).

2) M. Yamazaki, H. Shirota, Shoyakugaku Zasshi, 35, 96 (1981).

3) M. Kubo, M. Nogami, M. Nishimura, T. Morita, S. Arichi, Yakugaku Zasshi, 103, 442 (1983).

4) H. Matsuda, Y. Li, K. Taniguchi, J. Yamahara, Y. Tamai, Yakugaku Zasshi, 111, 36 (1991).

5) M. A. Perry, S. Wadhwa, D. A. Parks, W. Pickard, D. N. Granger, Gastroenterology, 90, 362 (1986).

6) T. Takemura, T. Yoshikawa, N. Yoshida, Scand. J. Gastroenterol., 24 (suppl), 51 (1988).

7) G. Pihan, C. Regillo, S. Szabo, Dig. Dis. Sci., 32, 1395 (1987).

8) D. N. Granger, G. Rutili, J. M. McCond, Gastroenterology, 81, 22 (1981).

9) Y. Kano, T. Sakurai, K. Saito, Shoyakugaku Zasshi, 43, 199 (1989).

10) T. Sakurai, H. Yamada, K. Saito, Y. Kano, Biol. Pharm. Bull., 16, 142 (1993).

11) Y. Kano, K. Komatsu, K.Saito, H. Bando, T. Sakurai, Chem. Pharm. Bull., 37, 193 (1989). 
12) B. Djahanguiri, Scand. J. Gastroenterol., 4, 265 (1969).

13) K. Takagi, S. Okabe, Jpn. J. Pharmacol., 18, 9 (1968).

14) M. Itoh, P. H. Guth, Gastroenterology, 88, 1162 (1985).

15) S. Marklund, G. Marklund, Eur. J. Biochem., 47, 469 (1974).

16) S. Oka, K. Ogino, T. Hobara, S. Yoshimura, Y. Okazaki, T. Takemoto, Y. Iida, Eur. J. Pharmacol., 197, 99 (1991).

17) M. A. K. Markwell, S. M. Haas, N. E. Tolbert, L. L. Bieber, "Methods in Enzymology," Vol. 72, Academic Press, Inc., New York, 1981, p.296.

18) J. R. Vane, Nature (London), 231, 232 (1971)

19) F. J. Van del Ouderaa, M. Buytenhek, D. H. Nugteren, D. A. Van dorp, Eur. J. Biochem., 109, 1 (1980).

20) A. Robert, J. E. Nezamis, C. Lancaster, A. J. Hanchar, Gastroenterology, 77, 433 (1979).

21) S. Okabe, H. Tanaka, "Pharmaceutical Research and Development," Vol. 23, 2nd ed., ed. by H. Saito, Y. Nomura, Hirokawa Publishing Co., Tokyo, 1990, p. 135.

22) P. M. Vaananen, J. B. Meddings, J. L. Wallace, Am. J. Physiol., 256, G470 (1991)

23) T. Yoshikawa, H. Miyagawa, N. Yoshida, S. Sugino, M. Kondo, J. Clin. Biochem. Nutr., 1, 271 (1986).

24) S. M. Smith, M. B. Grisham, E. A. Manci, D. N. Granger, P. R. Kvietys, Gastroenterology, 92, 950 (1987).

25) C. Peeters-Joris, A. Vandevoorde, P. Baudhuin, Biochem. J., 150,
31 (1975)

26) S. Hashimoto, Anal. Biochem., 62, 426 (1974)

27) A. S. Salim, F. Fcicd, Am. J. Med. Sci., 300, 1 (1990).

28) R. Menguy, L. Desbaillets, Y. F. Masters, Gastroenterology, 66, 46 (1974).

29) S. K. Cunningham, T. V. Keaveny, Ir. J. Med. Sci., 146, 136 (1977).

30) J. M. McCord, R. S. Roy, Can. J. Physiol. Pharmacol., 60, 1346 (1982).

31) W. R. Waud, K. V. Rajagopalon, Arch. Biochem. Biophys., 172, 365 (1976).

32) G. T. Truscott, J. Photochem. Photobiol. B: Biol., 6, 359 (1990).

33) P. F. Conn, W. Schalch, T. G. Truscott, J. Photochem. Photobiol. B: Biol., 11, 41 (1991).

34) T. P. A. Devasagayama, T. Werner, H. Ippendorf, H. Martin, H. Sies, Photochem. Photobiol., 55, 511 (1992).

35) A. D. Muir, A. L. J. Cole, J. R. L. Walker, Planta Med., 44, 129 (1982).

36) S. Tanaka, Y. Ikeshiro, M. Tabata, M. Konoshima, Arzneim.Forsch./Drug Res., 27, 2039 (1977).

37) Y. Fujimoto, M. Satoh, Phytochemistry, 26, 2850 (1987).

38) A. D. Patil, W. C. Kokke, S. Cochran, T. A. Francis, T. Tomszek, J. W. Westley, J. Nat. Prod., 55, 1170 (1992). 